\title{
The German labor market after the Great Recession: successful reforms and future challenges
}

\author{
Marco Caliendo ${ }^{1,3^{*}}$ and Jens Hogenacker ${ }^{2}$
}

\author{
* Correspondence: \\ caliendo@uni-potsdam.de \\ ${ }^{1}$ University of Potsdam, IZA Bonn, \\ DIW Berlin, IAB Nuremberg, \\ Potsdam, Germany \\ ${ }^{3}$ Chair of Empirical Economics, \\ August-Bebel-Str. 89, 14482, \\ Potsdam, Germany \\ Full list of author information is \\ available at the end of the article
}

\begin{abstract}
The reaction of the German labor market to the Great Recession 2008/09 was relatively mild - especially compared to other countries. The reason lies not only in the specific type of the recession - which was favorable for the German economy structure - but also in a series of labor market reforms initiated between 2002 and 2005 altering, inter alia, labor supply incentives. However, irrespective of the mild response to the Great Recession, there are a number of substantial future challenges the German labor market will soon have to face. Female labor supply still lies well below that of other countries and a massive demographic change over the next 50 years will have substantial effects on labor supply as well as the pension system. In addition, due to a skill-biased technological change over the next decades, firms will face problems of finding employees with adequate skills. The aim of this paper is threefold. First, we outline why the German labor market reacted in such a mild fashion, describe current economic trends of the labor market in light of general trends in the European Union, and reveal some of the main associated challenges. Thereafter, the paper analyzes recent reforms of the main institutional settings of the labor market which influence labor supply. Finally, based on the status quo of these institutional settings, the paper gives a brief overview of strategies to combat adequately the challenges in terms of labor supply and to ensure economic growth in the future.
\end{abstract}

Keywords: Unemployment, Labor force participation, Labor supply, Benefit systems, Public policy

JEL codes: J26, J38, J68

\section{Introduction}

The reaction of the German labor market to the Great Recession 2008/09 was - especially compared to other countries - relatively mild. This "German Miracle" occurred due to various reasons. On the one hand, Germany had to - unlike countries such as Ireland and the United States, which both faced a slump in domestic demand combined with a real estate crisis - deal with a world demand shock that mostly affected economically strong firms (Rinne and Zimmermann 2011; Schneider and Gräf 2010). On the other hand, various flexibility instruments at the firm level, combined with discretionary adjustments of the institutional framework by policy makers (i.e. enhancement of the short-time work schemes), enabled firms to adjust their workforce along the internal rather than the

\section{Springer}

(c) 2012 Caliendo and Hogenacker; licensee Springer. This is an Open Access article distributed under the terms of the Creative Commons Attribution License (http://creativecommons.org/licenses/by/2.0), which permits unrestricted use, distribution, and reproduction in any medium, provided the original work is properly cited. 
external margin (Möller 2010). In addition, far reaching labor market reforms between 2002 and 2005, initiated to fight the high and persistent unemployment that had evolved since the end of the seventies, had significantly altered the core elements of the labor market, including active and passive labor market policies, the organizational structure of labor offices as well as the pension system. The speed and depth of the reforms were quite remarkable when it is considered that the German welfare state had been typically depicted as the prime example of a "frozen welfare state", highly resistant to change (see, among others, Esping-Andersen 1990; Manow and Seils 2000; Kemmerling and Bruttel 2005; Konle-Seidl et al. 2010). In summary, the actions taken during the reforms led to higher working incentives and better matching between labor demand and supply in the period before the Great Recession, and were therefore considered as one of the main reasons for the mild reaction (Gartner and Klinger 2010). The reforms also had the general goal of increasing the labor force participation of those with young families.

However, irrespective of the mild response to the Great Recession, there are a number of substantial future challenges the German labor market will soon have to face. Since Germany will - like many other Western European countries - further experience a massive demographic change over the next 50 years, the development of labor supply of women and older people will become increasingly important in determining the extent to which the working population will decrease (OECD, 2005). Although the employment rates of both groups have in recent years increased, challenges still remain. The current tax and transfer system has so far favored the sole male bread-winner model and therefore causes the absolute working-time hours of economically active women to lie well below that of other Western European countries. Together with the trend of a persistent low fertility rate, the sustainable economic growth of Germany is in jeopardy in the near future due to a decrease of employment potential (OECD 2012). Moreover - although the employment rate of older people lies well above the EU-27 average and has also significantly increased since 2002 - the actual average retirement age continues to lie well below the statutory retirement age. This means there is some maneuverability for potential improvement. However, since older people are often discriminated against in favor of younger people, which often results from a misperception of their working potential, there is not only a need for further social benefit reform, but also for enhancing prospects of lifelong learning (Eichhorst 2011). Labor demand of firms is expected to decrease less than labor supply over the next decades (Sachverständigenrat zur Begutachtung der gesamtwirtschaftlichen Entwicklung (SVR), 2011), and due to a persistent skill-biased technological change - inducing a decrease of low-skilled jobs in the industry and a considerable growth in occupations requiring higher skills (Spitz-Oener 2006; OECD 2011a) - firms will find it harder to find employees with adequate skills. Employment opportunities for individuals with low education levels will significantly decrease (European Centre for the Development of Vocational Training, 2010), emphasizing the need for facilitating access to higher education for a larger share of the population.

The aim of this paper is threefold. First, it analyzes past reforms of main institutional settings of the labor market which have influenced labor supply in Section 2. We outline the political and economic situation before 2002 and provide a brief description of the first set of labor market reforms in Section 2.1. This is followed by a discussion of 
the most relevant income support systems: unemployment benefits and social assistance (see Section 2.2); pensions and early retirement (see Section 2.4); and active labor market policies, since the most recent reforms put an emphasis on increasing labor supply incentives as well (see Section 2.3). Wherever possible, we summarize the effects of these reforms in a comprehensive way. Furthermore, the paper outlines why the German labor market reacted in such a mild fashion during the "Great Recession" (Section 3.1), describes current economic trends of the labor market in light of general trends in the European Union, and reveals some of the main challenges associated with these trends in Section 3.2. The challenges for the education system and lifelong learning are discussed in Section 4.1, before an examination of the role of the current tax system in Section 4.2 and a recent initiative to increase labor supply of young families in Section 4.3 are introduced. Based on the status quo of these institutional settings, the paper also provides an overview of strategies to combat the above-mentioned challenges in terms of labor supply and to ensure economic growth in the future.

\section{Institutional settings and labor market reforms in the last decade}

\subsection{The economic situation before $\mathbf{2 0 0 2}$ and the first set of labor market reforms}

Many European countries had to face high unemployment rates in the 1990s, but Germany had especially proven to be unable to benefit from favorable conditions in the global economy by that time. At only 1.8\%, GDP growth between 1991 and 2003 was only half of the UK growth rate, leading to decreasing employment and increasing unemployment (Jacobi and Kluve 2007). Germany's slow response to the worsening labor market situation can only be explained by a long period of reform blockage and postponement in labor market policy adjustments (Reformstau, see Eichhorst and Marx 2009). Reunification in 1990 certainly played a major role, where ALMP (and passive income support systems, like early retirement) were used to take "surplus labor" out of the labor market. A clear indication of this is that the number of participants in jobcreation schemes and training programs in 1992 exceeded the number of unemployed in East Germany. Since deficits in the unemployment insurance schemes and the budget of the Federal Employment Agency (FEA) were either covered by the federal government or by higher contributions of employers and employees, this resulted in rising non-wage labor costs which in turn hampered employment creation (Konle-Seidl et al. 2010). The left-wing coalition in power since 1998 was torn between stabilizing the traditional "German social policy" approach and introducing the concept of an "activating state" in UK "New Labour" style.

The first step made effective from January 1, 2002, was the so-called Job-AQTIV amendment, which changed the focus of German labor market policy from a reactive to an activating one (Wunsch 2006). The main elements of this amendment were the introduction of qualitative profiling of job-seekers upon unemployment registration with the Local Employment Agency (LEA) and the establishment of a compulsory written agreement between the LEA and the job-seeker (Eingliederungsvereinbarung) in order to determine the duties and efforts of both contracting parties during the job-search process. In addition strategies were put in place to reach re-placement targets. The amendment postulated a more appropriate and flexible use of ALMPs and simplified other ones (Wunsch 2006). Comprehensive evaluations of ALMPs were explicitly enshrined in the law by the Job-AQTIV amendment ( $\$ 282$, Social Code (SC) III) for the first time. 
When the FEA was accused of massive fraud in reporting successful job placements in the beginning of 2002, the government took advantage of this scandal and appointed an independent expert commission, which worked out the blueprint for the reform package known as the Hartz Reforms ${ }^{1}$. This reform package consisted of four laws (Hartz I-IV), which were implemented incrementally between January 1, 2003, and January 1, 2005, and introduced some rather radical changes in German labor market policy. Hartz I introduced the concept of personnel service agencies (Personal-ServiceAgenturen), which were attached to LEAs and were supposed to employ unemployed individuals, hire them out to companies and organizations, and train them when not hired out. Hartz I also tightened the conditions for the acceptability of jobs and introduced training vouchers unemployed individuals could use to get training from approved providers. The second amendment, Hartz II, introduced new regulations for minor jobs (Mini- and Midi-Jobs) and a second start-up subsidy (Ich-AG) for unemployed individuals starting in self-employment (in addition to an already existing start-up subsidy scheme). Hartz III addressed the organizational structure of public employment services, and altered existing programs, as well as introducing new ones, within the area of ALMP (for more details, see Section 2.3).

\subsection{Unemployment benefits, social assistance and Hartz IV}

The Hartz IV amendment had the most dramatic change, since it replaced the former unemployment assistance and social assistance by a single means-tested replacement scheme for needy unemployed job-seekers and their household. Prior to the reforms, Germany had a system of income protection which was based on three pillars: 1) unemployment benefits, 2) unemployment assistance and 3) social assistance. The following brief description of these three elements will help for comparison with the new system (see Konle-Seidl et al. 2010, for a detailed description).

Unemployment benefits (UB, Arbeitslosengeld) provided earnings-related income replacement for a limited duration of 6 to 32 months if the unemployed individual had been in employment covered by social insurance for at least 12 months. The legal basis for UB was the SC III. The replacement rate of UB was dependent on family status, while the duration was dependent on age and previous employment duration. Unemployed individuals with at least one child were entitled to $67 \%$ of net remuneration and $60 \%$ otherwise. UB claims were based on an employment record and provided benefits proportional to prior earnings within the reference period. Individual means or needs were not taken into account. The maximum duration of UB varied between 6 to 32 months. Workers who had been employed less than 12 months within the last seven years before entering unemployment were not entitled for UB, whereas 12 months of employment meant a claim period of six months. This period rose proportionally to the number of months in employment. However, several discontinuities with respect to age existed (see Table 1). For someone under 45, the maximum entitlement period was 12 months (given a minimum employment period of at least 24 months), whereas people above 45 (and under 47) could claim up to 18 months. Further discontinuities were built in at age 47 (up to 22 months), 52 (up to 26 months) and 57 (up to 32 months). The benefits were funded by matching employer and employee contributions and administered by the FEA, which was traditionally also in charge of implementing ALMPs. 


\begin{tabular}{|c|c|c|c|c|c|}
\hline $\begin{array}{l}\text { Length of benefit } \\
\text { entitlement } \\
\text { (in months) }\end{array}$ & $\begin{array}{c}\text { Age } \\
\text { (in years) }\end{array}$ & $\begin{array}{l}\text { Months worked } \\
\text { in last } 7 \text { years }\end{array}$ & $\begin{array}{l}\text { Length of benefit } \\
\text { entitlement } \\
\text { (in months) }\end{array}$ & $\begin{array}{c}\text { Age } \\
\text { (in years) }\end{array}$ & $\begin{array}{l}\text { Months worked } \\
\text { in last } 5 / 7 \text { years }\end{array}$ \\
\hline \multicolumn{3}{|c|}{ Prior to the Hartz Reforms } & \multicolumn{3}{|c|}{ February 1, 2006 - February 28, 2008} \\
\hline 6 & - & 12 & 6 & - & 12 \\
\hline 8 & - & 16 & 8 & - & 16 \\
\hline 10 & - & 20 & 10 & - & 20 \\
\hline 12 & - & 24 & 12 & - & 24 \\
\hline 14 & 45 & 28 & 15 & 55 & 30 \\
\hline 16 & 45 & 32 & 18 & 58 & 36 \\
\hline 18 & 45 & 36 & \multicolumn{3}{|c|}{ Since March 1, 2008} \\
\hline 20 & 47 & 40 & 6 & - & 12 \\
\hline 22 & 47 & 44 & 8 & - & 16 \\
\hline 24 & 52 & 48 & 10 & - & 20 \\
\hline 26 & 52 & 52 & 12 & - & 24 \\
\hline 28 & 57 & 56 & 15 & 50 & 30 \\
\hline 30 & 57 & 60 & 18 & 55 & 36 \\
\hline 32 & 57 & 64 & 24 & 58 & 48 \\
\hline
\end{tabular}

Source: SC III (\$117 et seq.).

After the UB entitlement period had expired, unemployed individuals were, in principle, eligible for unlimited and means-tested unemployment assistance (UA, Arbeitslosenhilfe). These benefits were still earnings-related (57\% / 53\% replacement rate with/without children) and provided income support for unemployed people who had some prior employment experience but had become long-term unemployed. In contrast to UB, UA was granted for an unlimited period (as long as individuals were available for the labor market) and funded by the Federal budget, that is, by general taxation. This scheme was also implemented by the FEA. In principle, recipients of UA had access to similar active labor market schemes as UB recipients. This distinction becomes important when we discuss the reformed system.

Finally, social assistance (SA, Sozialhilfe), provided basic income protection on a meanstested and flat-rate basis for all German inhabitants. This assistance was independent of employment experience but conditional on not having other resources of earned income, social benefits or family transfers. Therefore, SA was a safety net for unemployed individuals with either no employment experience or unemployment benefit/assistance claims that did not match the guaranteed minimum income. Konle-Seidl et al. (2010) note that meanstesting was harsher in the SA scheme (compared to the UA scheme) and every job was considered acceptable. SA was funded by the municipalities that were also responsible for reintegrating recipients into the labor market through specific active measures. A fairly rudimentary labor market policy scheme was available - called "Help to Work" - and operated by the municipalities, with a considerable scope of discretion. There was no entitlement to integration measures by the FEA (Konle-Seidl et al. 2010) and even if capable of work, many of those in need were not registered as unemployed with the FEA (Bernhard et al., 2008). 
At the beginning of 2005 and with the fourth amendment of the Hartz Reforms, SC II came into force with some major changes in the system. Most importantly, the former unemployment assistance and social assistance were replaced by a single means-tested replacement scheme - unemployment benefit II (UB-II, Arbeitslosengeld II) - for needy unemployed job-seekers and their household. This scheme is tax-financed and covers needy job-seekers who are capable of working but not entitled to unemployment benefits - now called unemployment benefits I (UB-I, Arbeitslosengeld I) - or after UB-I has expired. The amount of UB-II does not depend on former income and needy job-seekers and their household are predominately registered as unemployed and may receive employment services (different from those for UB-I recipients). For UB-I recipients, the most drastic change concerned the duration of benefit entitlement (see Table 1). The maximum duration was cut down to 12 months for people aged below 58 years. For people aged above this threshold the maximum duration was elevated to 24 months, but only if they had worked for at least 48 months in the last five years before becoming unemployed. Initially, the reductions were even more severe before they were relaxed again due to political unrest. Between February 1, 2006, and February 28, 2008, only two discontinuities were in place: for people aged at least 55, the maximum duration was set to 15 months (with 30 months of employment before) and 18 months (with at least 36 months of employment).

The Hartz Reforms radically changed the German system of wage-related welfare. In contrast to the old scheme, the new UB-II system now had a dual aim. Although designed to prevent poverty, it does not secure previous living standards. Thus, for those having received social assistance before, the new legislation actually allows them to receive marginally more money and access to job employment services (Konle-Seidl et al. 2010). For former recipients of UA, the level of transfer payment decreased. Apart from its social policy objective, the aim of the reform was to lower unemployment but also to ease the burden of taxation and non-wage labor costs by reducing benefit dependency. The major lever to achieve this goal was the shortening of individual unemployment spells through accelerated job placement and more coherent activation of the beneficiaries of unemployment insurance benefits and unemployment or social assistance. Less generous benefits for long-term unemployed, stricter job suitability criteria and more effective job placement and active labor market schemes were the instruments to achieve this goal.

Only a few empirical studies have evaluated the macroeconomic effects of the Hartz Reforms in detail. Fahr and Sunde (2009) as well as Klinger and Rothe (2010) use a stock-flow matching approach based on administrative data from the FEA to determine the speed of unemployment outflows after the first three Hartz Reforms. Their results indicate that the first two reform waves did indeed have a significant positive impact on the process of job creation. Both studies, however, emphasize that their results might be prone to measurement error, since the FEA changed definitions and statistics during the reform process, often making clear-cut identification strategies impossible. Furthermore, the studies also make no statements concerning the quality and the duration of new jobs.

To sum up, the Hartz Reforms between 2002 and 2005 considerably changed the institutional settings of the labor market in Germany. However, not only had the passive labor market policy (i.e. social assistance and unemployment benefits) been changed 
considerably. There was also a significant reframing of the ALMP during the Hartz Reforms, which we describe in the following section.

\subsection{Active labor market policy}

Germany has a long tradition in the provision of ALMPs, and their expenses range among the highest in the budget of the FEA (for comprehensive overviews, see, among others, Caliendo and Steiner 2005; Wunsch 2006; Bernhard Hohmeyer et al. 2008b; Eichhorst and Zimmermann 2007). ALMP programs generally aim at increasing the employability of the unemployed to support their integration into the labor market. In contrast to many other policy schemes, ALMPs have always been subject to a consistent and dynamic transition in the light of structural and societal adjustment processes of the labor market (Heyer et al. 2011). There are three main categories of ALMPs: subsidized employment, labor market training, and public job-creation schemes. Whereas the first includes schemes targeted at the long-term integration of unemployed individuals into the first labor market through temporary subsidies (i.e. wage and start-up subsidies), the second aims at enhancing the chances for re-employment through various measures of short-term and further vocational training. The third is targeted especially at the longterm unemployed with minor prospects of a swift integration into the first labor market (i.e. 1-Euro-Jobs).

During the Hartz Reforms, a crucial shift had been made towards ALMPs that require a more proactive behavior of unemployed individuals. Jacobi and Kluve (2007) describe the Hartz Reforms as a tripartite reform strategy aimed at: (1) improving labor market services and policy measures in terms of effectiveness and efficiency; (2) activating the unemployed based on the principle of "rights and duties" (Fördern und Fordern); and finally (3) stimulating labor demand by deregulating the labor market. More specifically, since the Hartz Reforms, unemployed individuals have had to carry out all necessary duties set out in an integration agreement (Eingliederungsvereinbarung) to become reintegrated into the labor market (Konle-Seidl et al. 2010). These agreements result from the profiling process of the unemployed, listing the services that will be provided to the job-seeker as well as the job-seeker's obligation towards the employment agency, for example in terms of job-search activities and participation in labor market programs. The Hartz Reforms also introduced sanction elements in order to effectively monitor the unemployed's search activities and personal efforts to return into the regular labor market. Sanctions in form of temporary benefit reductions could be used, if the unemployed individual does not comply with the integration agreement or does not accept a suitable offer to work. Furthermore, an improved targeting of active measures and a better allocation of resources were additional aims. This was mainly done by profiling "customers" into four types and addressing their needs accordingly. Finally, it was also agreed upon to conduct rigorously scientific evaluations of all the measures (see Jacobi and Kluve 2007, for more details).

As part of the reform realignments in 2003, integration subsidies were redesigned and new forms of wage subsidies, start-up subsidies as well as jobs with reduced social security contributions were introduced. Emphasis was shifted away from public jobcreation schemes, which have been proven to be ineffective (Caliendo et al. 2008). Since then, ALMP in Germany has undergone a further two major reforms, which came into effect in the beginning of 2009 and 2012. Both required considerable changes in the 
Table 2 Entries into selected labor market programs between 2006 and 2011

\begin{tabular}{lcccccc}
\hline & $\mathbf{2 0 0 6}$ & $\mathbf{2 0 0 7}$ & $\mathbf{2 0 0 8}$ & $\mathbf{2 0 0 9}$ & $\mathbf{2 0 1 0}$ & $\mathbf{2 0 1 1}$ \\
\hline Entries into program & & & & & & \\
Wage subsidies (Eingliederungszuschüsse) & & & & & & \\
SC II & 106,300 & 135,800 & 124,000 & 127,300 & 85,900 & 115,100 \\
SC III & 120,200 & 123,600 & 139,700 & 149,900 & 66,000 & 85,900 \\
Further vocational training (Berufl. Weiterbildung) & & & & & \\
SC II & 110,300 & 167,200 & 225,500 & 244,600 & 141,500 & 166,500 \\
SC III & 154,500 & 211,300 & 260,000 & 400,400 & 211,100 & 158,300 \\
Public job creation I (Arbeitsbeschaffungsmaßnahmen) & & & & & \\
SC II & 62,400 & 53,000 & 64,000 & 6,100 & 51 & 56 \\
SC III & 16,700 & 16,200 & 6,500 & 5,000 & 1,600 & 1,200 \\
Public job creation II (1-Euro-Jobs) & 741,900 & 798,700 & 823,200 & 812,300 & 421,000 & 475,200 \\
Short-term training (Trainingsmaßnahmen) & & & & & & \\
SC II & 444,100 & 546,000 & 627,700 & 256,700 & 1,100 & - \\
SC III & 533,600 & 519,800 & 586,900 & 229,500 & 161 & - \\
Contracting-out placement services (Beauftragung Dritter) & & & & & \\
SC II & 140,400 & 119,400 & 189,800 & 105,700 & - & - \\
SC III & 142,600 & 120,700 & 254,000 & 108,200 & - & - \\
Start-up subsidy (Ich-AG) & 42,800 & - & - & - & - & - \\
Bridging allowance (Überbrückungsgeld) & 108,300 & - & - & - & - & - \\
New-start up subsidy (Gründungszuschuss) & 33,600 & 126,000 & 119,300 & 137,100 & 146,500 & 133,800 \\
\hline Soure: Yealy Stistcs of the Fera
\end{tabular}

Source: Yearly Statistics of the Federal Employment Agency.

legal framework, which again involved the introduction of new schemes as well as the abolishment and redevelopment of old ones. Table 2 contains the number of entries in selected programs for 2006 to 2011, distinguished by individuals falling under SC III and needy job-seekers under SC II.

The most important programs covered by Social Code III are currently targeted wage subsidies, start-up subsidies and further vocational training. During the 2009 reform, the activation measures, short-term training and private placement services (contracting out) were subsumed under a general paragraph, making separate regulations for both schemes obsolete (Steinke et al. 2012). Therefore, the yearly entry statistics of the FEA no longer distinguishes between the two schemes. However, they are still considered to be important instruments in both legal frameworks (Heyer et al. 2011). By far, the most important program covered by SC II in terms of yearly entries is public job-creation schemes (1-Euro-Jobs; see Hohmeyer and Wolff 2007).

All programs and organizational changes have been (and are currently still) evaluated as part of the legal obligation contained in the Hartz Reforms. Since there are hardly any social experiments on German ALMPs, the comparison usually relies on statistical techniques to create an appropriate control group ${ }^{2}$. This has led to a broad collection on evaluation results on the effects of 1-Euro-Jobs (Hohmeyer 2009), benefit sanctions (Schneider 2008), start-up subsidies (Baumgartner and Caliendo 2008, Caliendo 2009, Caliendo and Kritikos 2009, and 
Table 3 Effects of selected labor market programs

\begin{tabular}{|c|c|c|c|}
\hline Study & Instrument/Program & $\begin{array}{l}\text { Inflows and } \\
\text { Observation } \\
\text { Period }\end{array}$ & Main results \\
\hline \multirow{2}{*}{$\begin{array}{l}\text { Bernhard } \\
\text { et al. (2008a) }\end{array}$} & \multirow{2}{*}{$\begin{array}{l}\text { - Targeted wage subsidies paid } \\
\text { to employers for a limited period }\end{array}$} & - Feb-Apr 2005 & \multirow{2}{*}{$\begin{array}{l}\text { - Large and significant positive effects } \\
\text { of nearly } 40 \text { percentage points }\end{array}$} \\
\hline & & - 20 months & \\
\hline \multirow{2}{*}{$\begin{array}{l}\text { Bernhard and } \\
\text { Kruppe (2012) }\end{array}$} & \multirow[t]{2}{*}{ - Further vocational training } & - Feb-Apr 2005 & \multirow{2}{*}{$\begin{array}{l}\text { - Share of unemployment benefit ॥ } \\
\text { recipients decreases; employment } \\
\text { rate in the intermediate term } \\
\text { increases by up to } 13 \% \text {-points }\end{array}$} \\
\hline & & - 30 months & \\
\hline \multirow[t]{2}{*}{$\begin{array}{l}\text { Bernhard and } \\
\text { Wolff (2008) }\end{array}$} & \multirow[t]{2}{*}{$\begin{array}{l}\text { - Contracting out placement } \\
\text { services for UB-II recipients }\end{array}$} & - Feb-Apr 2005 & $\begin{array}{l}\text { - Locking-in effects in first months } \\
\text { after start }\end{array}$ \\
\hline & & - 25 months & $\begin{array}{l}\text { - Employment rates are raised by } \\
\text { about two \%-points for East German } \\
\text { participants and West German male } \\
\text { participants }\end{array}$ \\
\hline \multirow[t]{2}{*}{$\begin{array}{l}\text { Caliendo and } \\
\text { Künn (2011) }\end{array}$} & $\begin{array}{l}\text { - Bridging Allowance } \\
\text { (formerly } \S 57 \mathrm{SC} \text { III) }\end{array}$ & - Jul-Sep 2003 & \multirow{2}{*}{$\begin{array}{l}\text { - High employment and modest } \\
\text { income effects for participants; } \\
\text { considerable additional job creation } \\
\text { for bridging allowance (small job } \\
\text { creation for start-up subsidy) }\end{array}$} \\
\hline & $\begin{array}{l}\text { - Start-Up Subsidy } \\
\text { (formerly §421 SC III) }\end{array}$ & - 56 months & \\
\hline \multirow[t]{2}{*}{ Hohmeyer (2009) } & - Work opportunities/"1-Euro-Jobs" & - Feb-Apr 2005 & \multirow{2}{*}{$\begin{array}{l}\text { - Small positive employment effects } \\
28 \text { months after program start for } \\
\text { women in East and West Germany } \\
\text { as well as men in West Germany }\end{array}$} \\
\hline & - Paid in addition to UB ॥ & - 28 months & \\
\hline \multirow[t]{2}{*}{ Rinne et al. (2011) } & \multirow{2}{*}{$\begin{array}{l}\text { - Different program types of } \\
\text { further vocational training }\end{array}$} & - Year 2002 & \multirow{2}{*}{$\begin{array}{l}\text { - All program types have on average } \\
\text { a significant positive impact on } \\
\text { employment prospects } 24 \text { months } \\
\text { after program entry }\end{array}$} \\
\hline & & - 28 months & \\
\hline \multirow[t]{2}{*}{ Schneider (2008) } & \multirow{2}{*}{$\begin{array}{l}\text { - Benefit sanctions for UB ॥ } \\
\text { recipients not complying with } \\
\text { requirements supposed to fasten } \\
\text { reintegration in labor market }\end{array}$} & - Jan 2005 & \multirow{2}{*}{$\begin{array}{l}\text { - No significant effect on reservation } \\
\text { wage of UB I| recipients }\end{array}$} \\
\hline & & - 11 months & \\
\hline
\end{tabular}

Note: All studies use propensity score matching methods based on administrative data.

Caliendo and Künn 2011) and start-up subsidies for needy unemployed (Wolff and Nivorozhkin 2008), private placement services/contracting out (Bernhard and Wolff 2008), targeted wage subsidies (Bernhard et al. 2008a, 2008c), and further vocational training (Rinne et al. 2011; Bernhard and Kruppe 2012). Whereas start-up subsidies, and targeted wage subsidies have been found to be quite positive, the effects for 1-Euro-Jobs are rather negative (see Table 3). The effects of further vocational training programs are quite heterogeneous depending on the empirical method, observation period, and data source used (Rinne et al. 2011). Nevertheless, these results can provide sound guidance for policy makers in further developing the institutional framework to adjust to structural changes of the labor market (Heyer et al. 2011).

However, one main problem of impact evaluation in the dynamic field of ALMP are considerable time lags between program implementation and first evaluation results, which is mainly due to data and budget constraints, but also inevitable for ex-post analyses interested in medium- and long-term effects. Therefore, evaluation studies often refer to programs that have already been restructured. Moreover, there is still a considerable need for further research. Many schemes can only be insufficiently evaluated by standard statistical techniques. This mostly concerns activation measures such as vocational training for young individuals with a short labor market history (see, e.g., Caliendo et al. 2011). 


\subsection{The pension system and early retirement}

Germany has one of the most generous public pay-as-you-go (PAYGO) pension insurance systems in the world, providing pensions to all private- and public-sector dependent employees, with the exception of civil-servants and the self-employed. It leads to high effective replacement rates and low effective retirement ages. In 2011, the average retirement age in Germany was roughly 61 for both men and women and therefore still lay well below the current statutory retirement age of 67. Institutional settings in Germany have long provided various incentives for older people to exit the labor market before the statutory retirement age, some of which we describe here (for a more detailed overview, see Eichhorst 2011). On the other hand, there are also demand factors contributing to early retirement that interact with these institutional settings. Firms might want to replace older workers for younger ones due to various reasons. Finally, early retirement might be the only option for older workers, since they face limited or unattractive employment opportunities. In this section, we explore certain aspects of early retirement, with a focus on institutional settings and provide a brief overview of the main characteristics of the German pension system.

The core of the public pension system in Germany provides old-age pensions for workers aged 60 and older, disability pensions for workers under 60 and survivor benefits for spouses and children. It is often characterized as a three pillar scheme: the first pillar - the public retirement insurance (PRI, Gesetzliche Rentenversicherung) - contains the elements mentioned above. It is laid down in SC VI and covers about $85 \%$ of the German workforce including public-sector workers that are not civil servants. The second pillar includes the occupational and the subsidized pension scheme, whereas the third pillar contains elements of private pension plans, such as portfolios, real assets and private pensions that are not subsidized.

Early retirement schemes had rapidly grown due to a social policy shift at the beginning of the 1970s, which aimed at taking surplus labor out of the labor market and to replace old by young workers. This was done mostly because of industrial restructuring and to fight unemployment in times of weak economic growth. This policy shift initially led to a significant decline in the average retirement age until the 1980s, with a slight rebound afterwards (Arnds and Bonin 2002). After reunification, German labor market policy reinforced early retirement schemes again to avoid a substantial increase of unemployment within the new Länder. Only after a massive increase of social security contributions and non-wage labor costs as well as in the light of ramifications of the demographic change did the government fundamentally alter retirement policies through a series of reforms starting in the early 1990s. The last major amendment to the pension system took place in 2007 . The statutory retirement age of 65 will be gradually and incrementally raised to 67 . Starting from 2012, and with the birth cohort of 1947, the age limit will be increased by one month per year and birth cohort. This means that the birth cohort of 1958 will have to work up to the age of 66 . The mandatory retirement age of 67 will be reached for all birth cohorts born from 1964 onwards by 2029 (Bonin 2009).

The German pension system today still allows for certain transitions into early retirement, although in a much more restrictive way. In general, individuals may retire voluntarily at any time between 63 and the full statutory retirement age, which is currently the age of 67. As compensation for the longer duration of pension payments, however, the pension reform in 1989 reduced the pension by $0.3 \%$ for each month of commencement of the pension 
before the age of 65 (Bonin 2009). Since the pension reduction is imposed throughout the whole period of pension receipt, the aggregate pension loss can still be quite substantial, given the conditional life expectancy of above 15 years at retirement age (Berkel and Börsch-Supan 2003). Since 1957, the German pension system has allowed for transitions from unemployment into early retirement under varying conditions (Altersrente wegen Arbeitslosigkeit, SC VI \$237). Today, this pathway to early retirement is no longer possible for individuals born after January 1, 1952. Old-age part-time (Altersteilzeit) constitutes a different possibility to reduce labor supply. Individuals who have reached the age of 55 and have been subject to social security contributions for at least three out of the previous five years, have the possibility to halve their remaining working time until they reach the statutory retirement age. This can be done by (1) either reducing the volume of the previous working time by half right away for the whole period ("part-time model"); or (2) by continuing working full-time for the first half of the period and being released from work in the second half ("block model", see Wanger 2009, for an extensive description of the old-age part-time employment act, Altersteilzeitgesetz). Whether the individual takes the first or second option is subject to regulations within collective bargaining agreements between employers and employees. In both cases, the employee receives $70 \%$ of her former net wage while the employer contributes to the pension system on the basis of $90 \%$ of the employee's full-time employment compensation (Arnds and Bonin 2002). In 2010, 16.3\% of all newly retired individuals had previously been in old-age part-time. On average, men entered into one of the old-age part-time schemes at 57.6 (women at 57.0). Today, individuals in old-age part-time who were born before January 1, 1952 may still obtain reduced old-age pensions at 60 if they had arranged a part-time agreement with their employer before January 1, 2004.

To conclude, the early retirement policy of the 1970s has been reversed considerably in light of the demographic change and a sustainable financing of the social security system through a major policy shift, which started in the 1990s. The public turned away from the perception that early retirement was a necessary means to keep unemployment low and to force integration of young people into the labor market (Eichhorst 2011). In combination with fundamental labor market reforms, the labor market participation of older people has significantly increased since 2002 .

\section{Current labor market trends after the Great Recession in Germany}

The previous sections have shown that the Hartz Reforms considerably changed the institutional settings of the labor market in Germany. Moreover, we have outlined that considerable efforts had further been undertaken in other areas of income support systems, which are important for labor supply in Germany. However, these numerous accomplishments should not conceal that Germany will face a number of substantial future challenges, which we will start to elaborate on in the next sections. Before we do so, we will first describe why the German labor market reacted in such a mild fashion to the Great Recession in 2008/2009.

\subsection{The mild response during the Great Recession 2008/2009}

The reaction of the German labor market to the Great Recession 2008/2009 has been very different from that of former recessions. Although the German economy had on average been hit stronger by the slump in gross domestic product (GDP) than many 


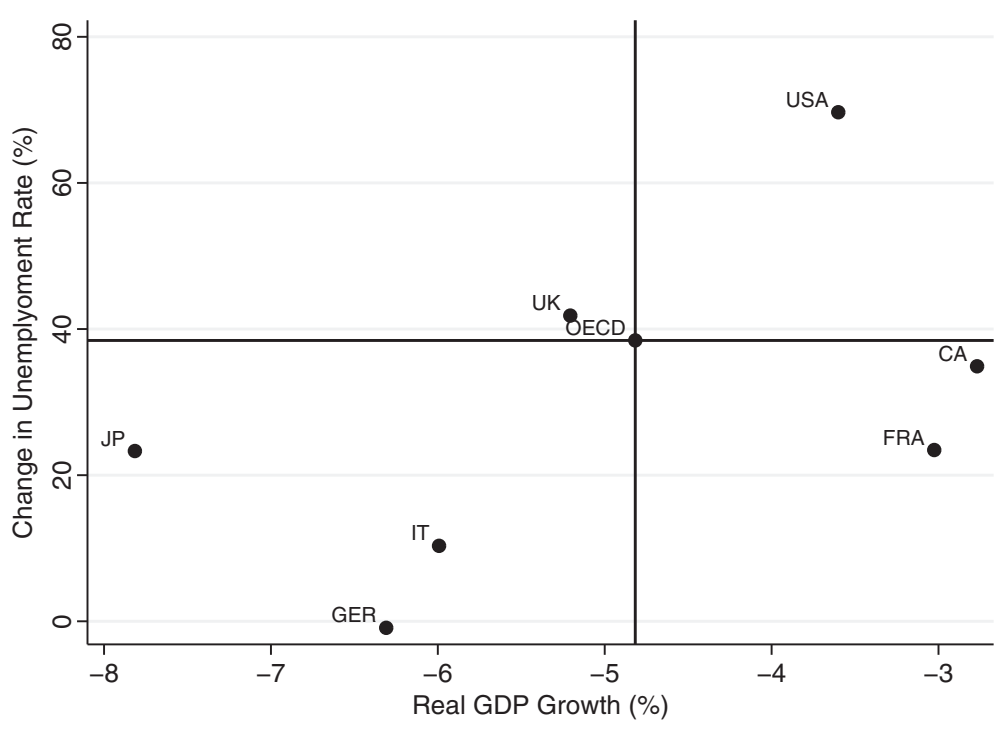

Figure 1 Change in harmonized unemployment rates vs. change in real GDP growth in Germany, G7 countries, and OECD -total: First half-year 2008 compared to first half-year 2009'. Source: OECD Statistics Database.

'GER-Germany, IT- Italy, JP-Japan, OECD-OECD-total, UK-United Kingdom, CA-Canada, FRA-France.

other countries in the Organisation of Economic Co-operation and Development (OECD), the increase in unemployment in the second quarter of 2009 was far lower than the OECD average (see Figure 1). This is largely due to the fact that, in contrast to Ireland and the United States for example, firms in Germany adjusted their working hours during this crisis almost solely along the intensive margin by reducing hours per worker. This unusual reaction compared to previous recessions was often depicted in the media as miraculous. However, it can be put into perspective by looking at three interdependent aspects - the previous labor market reforms, other flexibility instruments and the type of the recession - which we briefly do now.

As already described in the previous section, Germany had introduced profound reforms of the labor market, which fundamentally changed its institutional settings. With regard to the mild response, two direct consequences of these reforms stand out: First, the reduction of unemployment assistance and the aggravation of rules for suitable employment overall increased the matching efficiency on the labor market, which in turn also resulted in a decrease of long-term unemployment for the first time since the 1960s. Second, the fact that more unemployed individuals were willing to take up less-paid jobs as an outcome of the labor market reforms resulted in smaller wage pressure during collective negotiations. Combined with a decrease in collective trade agreements, this led to an average reduction of $2 \%$ of unit labor costs in Germany between 2000 and 2007, compared to an average increase of $22 \%$ amongst all other OECD countries in the same period (OECD 2012). These two structural adjustments towards a new equilibrium left the labor market in a robust condition at the eve of the Great Recession. Furthermore, the overall decrease in unit labor costs made it possible for firms to build up financial reserves during the economic upswing between 2006 and 2008, leaving them in a healthy financial state when the economic crisis began (Schneider and Gräf 2010). 
The second aspect has to do with other additional institutional factors which allowed a higher flexibility in Germany. In 2009, the overall working time of dependent employees was reduced by 41.3 hours $(3.1 \%)$ on average compared to the previous year (Fuchs et al. 2010). Basically, three instruments of working-time flexibility at the firm level (working-time accounts, working overtime and the reduction of weekly working hours) and one instrument at the state level (short-time work) involving subsidies from the FEA made this adjustment in working hours possible (Dietz et al. 2011). The first instrument at the firm level consisted of working-time accounts, which made it possible for firms to adjust the number of hours worked depending on the business cycle. During economic upswings, employees had accumulated working hours in their accounts through unpaid overtime, which they then used up with free time during the economic downturn. As a second instrument, paid working overtime was reduced by almost $20 \%$ in the first quarter of 2009 (Dietz et al. 2011). The last instrument at the firm level, reduction of weekly working hours, had recently been made more flexible due to new collective agreements, most of which were made in the manufacturing sector. The greatest reduction of average weekly full-time working hours was in the first quarter of 2009, with an average decrease of roughly one hour compared to the previous year (Dietz et al. 2011). Finally, short-time work (STW) was expanded dramatically during the Great Recession. In May 2009, around 1.5 million workers were drawing benefits from the STW scheme compared to 50,000 in September 2008, the month of the Lehmann insolvency (Statistik der Bundesagentur für Arbeit 2012). The main idea behind STW is to offer an alternative to firms to lower labor costs without having to lay off workers. At the moment there are three kinds of STW, out of which the so-called "STW for economic reasons" (\$96, SCB III) has mainly been applied during the economic crisis. A firm is eligible for this type of STW if it is able to claim that it suffers a temporary and inevitable loss or stoppage of working hours due to an aggravation of business conditions because of economic reasons. This stoppage must result in a loss of wages of more than $10 \%$ of the monthly gross earnings of at least one third of the firm's employees. Furthermore, the firm must have already applied all other possible flexibility options (i.e. reduction of overtime hours and the use of working-time accounts). Then for each worker, the FEA then pays the firm up to $67 \%$ of the individual net wage gap resulting from the loss of working hours for up to 24 months (Crimman and Wießner, 2009). Taking the average number of subsidized working hours into account, STW supposedly saved around 360,000 jobs (Möller 2010). In summary, the greatest contribution to the overall reduction of the annual working hours in 2009 compared to 2008 was $13 \%$ and resulted from STW. The reduction of weekly working hours contributed to the overall reduction with a share of roughly $10 \%$, whereas the reduction of paid overtime was almost $8 \%$. Finally, working-time accounts were responsible for $7 \%$ of the overall reduction of the yearly working hours (Fuchs et al. 2010).

The third aspect refers to the type of transmission mechanism through which the crisis was hitting Germany. Whereas Ireland, Spain and the United States had to deal with burdens resulting from structural adjustments due to the real estate crisis and turmoil within the financial sector, Germany had not experienced a housing bubble and was instead facing a fierce output decline due to a shortfall of world trade (Burda and Hunt 2011). This output decline primarily hit the export oriented manufacturing sector in Germany, which had experienced a strong upswing in the three previous years leading up to the crisis in 2008 with an output growth rate being twice as high compared to the 
aggregate economy (Möller 2010). Another established empirical fact is that firms engaging in international trade are more productive and innovative than non-exporting firms and, in the case of Germany, are mostly located in the manufacturing sector (Wagner 2011). Hence, the Great Recession hit the strongest firms coming from an upswing with profit shares between $42 \%$ and $45 \%$ in the three years leading up to the crisis (Eurostat 2012). Because of the foregone upswing, workers in the manufacturing sector had also accumulated a significant surplus of working hours on their working time accounts, which could then be used up during the crisis. It should also be stressed that flexibility instruments only work well if they are used to dampen a demand shock that has been induced externally and only lasts for a short period of time. This is why it worked in Germany better than in other European countries with similar schemes (Arpaia et al. 2010).

Taken together, these three aspects allowed firms to hoard labor deliberately, hoping to be prepared for the next economic boom where they would need an often highly specialized labor force.

\subsection{Labor supply and demographic change: future challenges ahead}

Although the mild response to the Great Recession 2008/2009 has shown that the German labor market has recently exhibited quite some resistance against external economic shocks, it should not be concealed that there are some substantial future challenges the German labor market will soon have to face. This becomes especially obvious in the light of the ongoing demographic change which Germany will experience over the next 50 years. As many other Western European countries, Germany experienced a steep increase in the average life expectancy of women and men aged 65 during the second half of the twentieth century, combined with a significantly decreased birth rate since the 1960s. Forecasts of the Federal Statistical Office project that the old-age dependency ratio ${ }^{3}$ will increase steeply until 2030 due to the baby boom generation retiring between 2015 and 2030. This demographic change will fundamentally challenge the labor market because it will lead to a decline in the economically active population. According to the baseline scenario ${ }^{4}$, the working population is expected to decrease by more than $30 \%$ until 2060 (Statistisches Bundesamt 2009). Under this scenario, labor supply in Germany will significantly diminish for the first time since World War II (SVR 2011). Hence, the question on how to maintain economic growth and sustainable financing of the public pension and health system despite the decrease has become very important. In this context, the development of labor supply of women and older people will therefore play a crucial role in determining the extent to which the working population decreases (OECD, 2005). The labor force participation of individuals aged 55 to 64 has admittedly risen significantly: In 2011, the employment rate of this age group was around 60\%, compared to $38 \%$ in 2001 (see Table 4), which was mainly caused by a rising female labor force participation (Garloff et al. 2012). Nevertheless, there are still incentives for older people to either retire before the statutory retirement age or to not seek employment because of limited or unattractive employment opportunities. Therefore, the main challenge concerning the future labor supply of older people is further increasing their working life, which could be achieved by either raising the retirement age or increasing the employability of older workers (OECD 2012). 
Table 4 Employment, unemployment and inactivity rates for 2011, by different age groups (in \%)

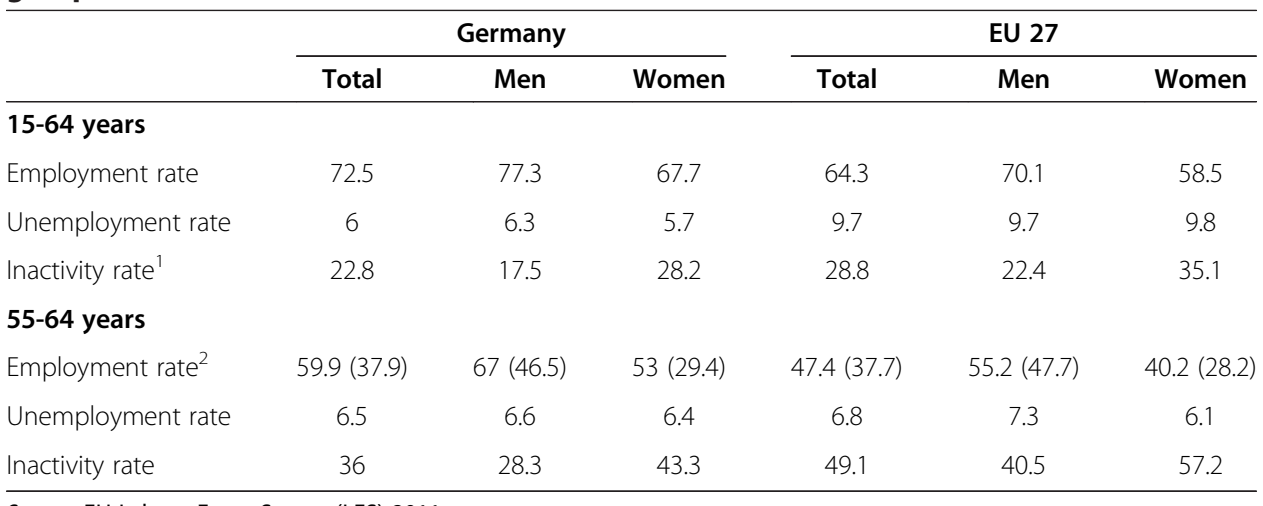

Source: EU-Labour Force Survey (LFS) 2011.

Notes: ${ }^{1}$ According to the definition of the International Labor Organisation (ILO), an individual is classified as inactive if he or she is not part of the labor force (i.e. not working at all and not available or looking for work either).

${ }^{2}$ Numbers in parentheses are for 2001.

Concerning the labor supply of women, it can be seen from Table 4 that the overall share of employed women of working-age in Germany (68\%) is 9 percentage points higher than the EU-27 average (59\%). However, the share of female individuals working part-time is also considerable higher ( $48 \%$ vs. $31 \%$, see Table 5$)$. Taking into account that around $15 \%$ of these women actually work part-time involuntarily, the low participation rate of women working full-time reflects negative incentives for an increase in working hours. These negative incentives arise, on the one hand, from the current tax and social welfare legislation in Germany, which still favors the sole male bread-winner model. On the other hand, childcare facilities allowing parents to work full-time only exist for $8 \%$ of the children under three in Germany.

For the overall labor market trend, another crucial component is the development of labor demand. Although projections of future labor demand are very difficult and prone to errors, it is generally expected that labor demand decreases less than labor supply (SVR 2011). If the persistent reduction of structural unemployment in Germany continues until 2020, many firms are expected to face the problem of skill mismatching (Fuchs and Zika 2010). Due to a persistent skill-biased technological change and increasing globalization, there will be a decrease of low-skilled jobs in the industry and a considerable growth in occupations requiring higher skills (Spitz-Oener 2006;

Table 5 Share of employed individuals (aged 25 to 64) working part-time and reasons for working part-time in 2011 (in \%)

\begin{tabular}{|c|c|c|c|c|c|c|}
\hline & \multicolumn{3}{|c|}{ Germany } & \multicolumn{3}{|c|}{$\mathrm{EU}-27$} \\
\hline & Total & Men & Women & Total & Men & Women \\
\hline Part-time $^{1}$ & 26.3 & 8.1 & 47.4 & 17.7 & 6.6 & 30.9 \\
\hline \multicolumn{7}{|l|}{ Reasons for working part-time } \\
\hline Undergoing education or training & 4.6 & 15.1 & 2.8 & 3.1 & 7.1 & 2.1 \\
\hline Looking after children or incapacitated adults & 24.7 & 4 & 28.3 & 26.4 & 5.3 & 31.6 \\
\hline Other family or personal reasons & 26.4 & 7.6 & 29.5 & 17.4 & 10 & 19.2 \\
\hline Involuntary part-time employment ${ }^{2}$ & 17.1 & 32.5 & 14.5 & 25.8 & 39.7 & 22.4 \\
\hline
\end{tabular}

Source: EU-LFS 2011.

Notes: ${ }^{1}$ According to the ILO, a part-time worker is "an employed person whose normal hours of work are less than those of comparable full-time workers" (Eurostat, 2008).

${ }^{2}$ As percentage of the total part-time employment. 
Table 6 Employment, unemployment, and inactivity rates of individuals aged 25-64 years by different education levels (in \%)

\begin{tabular}{|c|c|c|c|c|c|c|}
\hline & \multicolumn{3}{|c|}{ Germany } & \multicolumn{3}{|c|}{ EU-27 } \\
\hline & Total & Men & Women & Total & Men & Women \\
\hline \multicolumn{7}{|c|}{ High education (ISCED' level 5-6) } \\
\hline Employed & 87.9 & 91 & 84 & 83.7 & 87.4 & 80.4 \\
\hline Unemployed & 2.4 & 2.3 & 2.7 & 5.0 & 4.7 & 5.4 \\
\hline Inactive & 9.9 & 6.9 & 13.7 & 11.8 & 8.3 & 15.1 \\
\hline \multicolumn{7}{|c|}{ Low education (ISCED ${ }^{1}$ level 0-2) } \\
\hline Employed & 56.6 & 66.8 & 49.2 & 53.5 & 64.5 & 43.3 \\
\hline Unemployed & 13.9 & 15.7 & 12.1 & 14.8 & 14.7 & 14.9 \\
\hline Inactive & 34.4 & 20.8 & 43.9 & 37.2 & 24.5 & 49.2 \\
\hline
\end{tabular}

Source: EU-LFS 2011.

Notes: ${ }^{1}$ The International Standard Classification of Education (ISCED) of the OECD divides the levels of education in six categories: Pre-primary (level 1), primary (2), lower (3) and upper (4) secondary education, tertiary (5) education, and advanced research programs (6) leading to the award of an advanced research qualification.

OECD 2011a). Since this trend is expected to continue over the next ten years, employment opportunities for individuals with low education levels will significantly decrease (European Centre for the Development of Vocational Training, 2010). The significance of educational attainment for the labor market status can be seen from Table 6, which displays unemployment rates for the economically active population by education level for 2011 .

Whereas the average unemployment rate in the EU-27 for the economically active population (25-64) is roughly $15 \%$ for individuals with low education (ISCED ${ }^{5}$ level $\left.0-2\right)$, it is much lower (5\%) for high-skilled individuals (ISCED level 5-6). This relationship is even stronger for Germany: The unemployment rate for individuals aged 25 to 64 with low education is $14 \%$ and therefore seven times larger compared to highly educated individuals (2\%). Hence, low-educated people in Germany face a much higher risk of joblessness than in other European countries. In 2009, 26\% of the German population aged 25 to 34 had attained a tertiary education level. This share is below the OECD average (37\%) and had only slightly increased since 2002 (OECD, 2011d). Although Germany has on average a high participation rate in education of individuals aged 15 to 24 , it still has to catch up concerning the educational outcomes of pupils - when compared to other economically strong countries. According to the Programme for International Student Assessment (PISA) 2009 study, the reading and mathematical skills of 15-year-olds in Germany were significantly higher than the OECD average but well below the highest scores (OECD 2010). Therefore, the elevation of the general educational level is still considered to be a necessary requirement to sufficiently overcome the sectoral and societal changes of the German economy (SVR 2009).

\section{Future challenges for labor supply policies}

The previous sections have shown, that further reforms in various dimensions are necessary in light of the ongoing demographic and technological change. Since educational attainment concerning labor supply has become increasingly important, we explore some issues related to challenges the education system faces in Section 4.1. Section 4.2 describes why income splitting is still a source for reduced labor supply of women. The parental leave 
benefit (PLB, Elterngeld) as another instrument to tackle the problem of low full-time female labor supply is investigated in Section 4.3.

\subsection{Towards a new skill strategy: challenges of the education system}

Nowadays, there are basically two main challenges linked to the education system, both of which were described in Section 3.2. The demographic change means that the labor supply of older people is closely linked to their employability, and hence, improving strategies for lifelong learning. Second, due to the technological change, educational attainment has become increasingly important, which basically amounts to raising the overall education level and facilitating the access to tertiary education.

Financing on the job training for older people is less attractive for firms due to a shorter working life of these people. The share of 50 to 64-year old employees participating in on the job-training has declined by 2 percentage points since 2007 and is currently at 33\% (Autorengruppe Bildungsberichterstattung 2012). This is still fairly low compared to countries such as Sweden (OECD 2012). Moreover, there are still considerable misconceptions of the productivity of older employees. The assumption that working productivity decreases at an older age is wide spread. It is argued that cognitive and physical skills decrease at a steeper rate than working experience increases, leading to an overall decreasing working productivity (SVR 2011). This leads to age discrimination of older workers (OECD 2011b). Hence, there is a reduced hiring probability of older workers in Germany (Heywood, 2010). However, more recent studies provide evidence that working productivity does not decrease for older people (Malmberg et al. 2008; Göbel and Zwick 2009). A recent study by Börsch-Supan and Weiss (2011) shows that the overall productivity of older people even increases slightly. But even if firms were encouraged to employ older workers - which, for example, was initiated in recent years by introducing wage subsidies targeted at older workers who would be in danger of being laid off because of the seniority principle - training measures could still be improved since older workers apparently do not often receive the "right" training (Zwick 2011). In recent years, a number of collective agreements have explicitly incorporated the promotion of employability of older people, and a number of programs initiated by the Federal Government and several unions have been adopted to raise public awareness for the working potential and the discrimination of older people. These agreements are in harmony with the introduction of an amendment in 2006 (Allgemeines Gleichbehandlungsgesetz), which explicitly forbids discrimination because of gender, origin or age.

Besides raising the employability of older people, there is also a considerable need for raising the education level in general. As described in Section 3.2, population ageing and technological change will also increase the need for highly qualified individuals. Therefore, improving the access to tertiary education in Germany in combination with elevating the medium education level are considered to be of crucial importance (SVR 2011; OECD 2011a). Empirical studies stress that investments in education are most fruitful if made during early childhood (see Cunha and Heckman 2007). There is also empirical evidence pointing towards the fact that appropriate pre-primary education has a positive effect on subsequent labor market outcomes, especially for children from families in which the parents have only a low education (OECD, 2011a). Therefore, it is 
often claimed that public expenditures should be concentrated on early stages of life in order to assure an efficient allocation of these expenditures (SVR 2009). However, the current distribution of public expenditures on education is not in accordance with these insights. In 2009, the highest share was spent for general education (ISCED 1-4, $35 \%$ ) and tertiary education (ISCED 5-6, 18\%). Only 9\% of the budget was spent on pre-primary education (Autorengruppe Bildungsberichterstattung 2012). Hence, more efforts are still needed to expand pre-primary education and to place more emphasis on early childhood development. Experts propose the expansion of nursery schools for children aged 3 to 5 , which is leading towards the concept of a mandatory pre-school year before entering the primary education level (SVR 2009). Furthermore, the specific early tracking in Germany into different school types at the onset of secondary education level is often criticized because empirical studies show that early tracking increases inequality, especially for children with a migration background (Hanushek and Wössmann 2006). Early school tracking more or less determines the chances for an entrance qualification to the upper level secondary education, which is still the only regular path to university, and the tertiary education in Germany. As a result, policy implications aim at a complete withdraw from early school tracking or to at least a postponement of the decision to a later point in time (OECD 2012).

In light of an increasing number of young adults qualified for higher education, but a stagnating share of individuals actually taking up a tertiary education, the German government has already undertaken a number of measures to facilitate access to tertiary education. Apart from granting more autonomy to universities, the government also provides financial means to the different Länder, which in turn agreed to assure additional university places until 2020 .

\subsection{Income splitting as a source for reduced labor supply}

As described in Section 2.2, the number of hours worked by female employees in Germany is comparatively low by international standards. This is mainly due to a high share of female secondary-earners working only part-time for very few hours (OECD 2012). It is often argued that the current system of income taxation creates fiscal disincentives for secondary earners because Germany allows for "income splitting" between married partners with regards to income taxation (Ehegattensplitting, $\mathbb{\$} 32 \mathrm{a}$ (5) Einkommensteuergesetz). Since 1958, married couples living in the same household may choose between individual and joint taxation. When choosing the latter, the taxable income of both spouses is cumulated and the sum is then split in half. The income tax is calculated by applying the tax function to the result and doubled in a third step to determine the tax liability of the couple. As a result, the amount of the income tax of a married couple may be lower than the tax the same couple would have to pay if both spouses were taxed individually according to the principle of separate taxation (Schlick 2005). This results in a "splitting effect" and is seen by critics as a strong disincentive for non-working spouses to take up work in the first place or for secondary earners to start working full-time. In a progressive transfer system like the German one, the tax advantage within the system of income splitting is highest when earnings are distributed unevenly between both spouses. Hence, when taking up work or increasing hours worked, secondary earners are confronted with a high marginal tax

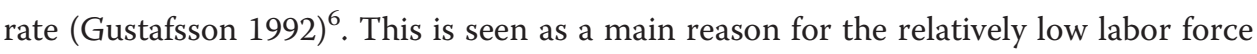
participation rate of married women in Germany. 
Therefore, altering the current system of joint taxation has been repeatedly proposed by experts to increase labor supply of women (OECD, 2011c, 2012). Steiner and Wrohlich (2004) use a micro-simulation model to estimate potential labor supply effects of a shift from joint taxation to individual taxation. The authors find that the female participation rate would increase by around 4.85 percentage points and the total number of hours worked by women would rise by $11 \%$. However, many public finance experts maintain the contrary by considering that there is no marriage gain from joint taxation at all. They rather argue that joint taxation is a logical consequence of the progressive tax system in Germany given the normative rule that taxation should be neutral with respect to the distribution of incomes within the household (Schlick 2005). Moreover, taxing on a purely individual basis may come into conflict with the constitutional law in Germany ${ }^{7}$.

In another paper, Dearing et al. (2007) compare Austria and Germany in terms of work incentives created by the tax and transfer system and childcare institutions. Both countries are quite similar in many institutional aspects but differ in their detailed characteristics concerning the tax system: while in Germany married spouses are taxed jointly and are eligible for full income splitting, Austria has a system of individual taxation. Moreover, Austria has a much more generous parental leave benefit (PLB, Elterngeld) system. Hence, it is interesting to note that labor force participation rates of mothers in Austria and Germany are similar. However, full-time employment rates are much higher among Austrian mothers. In order to establish to what extent these differences can be attributed to differences in the tax-transfer system, the authors estimate structural labor supply models for both countries and then interchange two important institutional characteristics: the definition of the tax unit within the personal income tax and the PLB scheme. The results show that differences in mothers' employment patterns can be partly explained by the different tax systems: individual taxation in Austria leads to lower marginal tax rates for secondary earners and increases labor supply incentives. The authors argue that labor force participation of German mothers would rise considerably if Germany were to introduce Austria's income tax and PLB characteristics.

However, it seems to be very unlikely that the current status quo concerning the joint taxation of married couples within a household will be changed any time soon, since this would also imply major changes in other parts of the social transfer system as a necessary condition in order to comply with constitutional norms (SVR, 2007). Nevertheless, there are a number of proposals considering alternative forms of joint taxation, ranging from a model of quasi-individual taxation where the personal exemption concerning the income tax is transferred from the non-working to the working spouse (OECD 2012) and to different systems of family taxation (for an overview, see SVR, 2007). These systems cannot be covered in detail here. We instead focus on another income support system that has been established in recent years with the aim to foster female labor supply.

\subsection{Parental leave benefit}

In addition to the low full-time labor force participation of women, Germany has also one of the lowest fertility rates in Western European countries, and there is little hope of expecting a substantial increase over the current rate of 1.4 any time soon (Spiess and Wrohlich 2008). Although these trends had already been observed, the German public has only just begun discussing these issues. The underlying reasons for this unfortunate mix - low fertility and low participation - can be seen as a result of a 
combination of various institutional arrangements preventing mothers from working full-time, for example an absence of childcare facilities, and rather strong and persistent preferences of (West-)German parents to care for young children at home (Bonin 2009). In addition, one should note that the labor force participation of mothers depends crucially on the child's age. Whereas only $11.5 \%$ of mothers whose youngest child is in its first year of age are in gainful employment, the share escalates to around $40 \%$ when the youngest child is between one and two years old. The highest employment share (78\%) is exhibited by mothers with the youngest child being between 12 and 15 (Bundesministerium für Familie, Senioren, Frauen und Jugend (BMFSFJ), 2010). In light of the demographic change and the need to secure future skill needs, it became obvious that facilitating the return to work for young mothers had gained in importance (Deutsches Institut für Wirtschaftsforschung (DIW), 2012). The German government therefore passed a reform of the PLB system (PLB, Elterngeld) in line with the Scandinavian model, which came into effect in the beginning of 2007 and replaced the means-tested preceding benefit (Erziehungsgeld $)^{8}$. The PLB is provided for up to 14 months to parents of children born on January 1, 2007 or later. The benefit replaces $67 \%$ of the average taxable income earned in the 12 months prior to the birth of the child for the parent staying at home ${ }^{9}$. The parent is eligible for benefit if he or she does not work full-time, which is defined as 30 hours per week. Besides the aim of increasing labor market participation of mothers with young children and fostering involvement in childcare of fathers, the reform also implicitly intended to increase fertility rates (Tamm 2009).

In 2009, the PLB was evaluated by the Federal Ministry for Families concerning the shortterm effects of the introduction of the benefit on employment behavior of parents with a new-born child (BMFSFJ, 2009). The study was based on a mail survey of a sample of parents $(N=1,595)$ whose child was born in April 2007 and who had applied for and received PLB. The study finds that the majority of young mothers resumed employment after having received PLB. Around 13\% of women took up part-time work again after six months, and 12 months after giving birth one third of all young mothers (31\%) were already re-employed. After 18 months the share was up to $39 \%$, reaching $42 \%$ after 24 months. However, two thirds of the women state that the infrastructure of childcare services is insufficient in their region. Along with the request of better in-firm childcare possibilities, these results indicate that the PLB only develops its full impact in combination with better early childcare services and more flexible models of working hours for women. To this date, only a few empirical studies have explicitly analyzed the impact of the PLB on the fertility rate mainly finding no statistically significant effects (Thyrian et al. 2010; Hoßmann et al. 2009).

\section{Conclusions}

The relatively mild reaction of the German labor market to the Great Recession 2008/09 was often called the "German Miracle". However, various reasons are able to explain this unusual response. First, the economic crisis mostly hit financially strong firms coming from a long upswing leading towards to the crisis. These firms were able to hoard labor deliberately due to a number of working-time flexibility instruments at the firm as well as the state level. Second, in the years prior to the Great Recession, Germany had introduced profound reforms of the labor market, which fundamentally changed its institutional settings as well as income support systems and overall led to higher working incentives and better matching between labor demand and supply. There was also a considerable 
reframing of ALMPs in the course of the labor market reforms, which led to a broad collection on evaluation results providing sound guidance for policy makers in further developing the institutional framework to adjust to structural changes on the labor market. Overall, it is fair to say that Germany has been on the right track with the main reforms of the labor market for the last 10 years.

Despite the mild response to the Great Recession, however, the paper has shown that there are a number of substantial future challenges the German labor market will soon have to face. Although the employment rate of women has recently grown considerably, the current tax and transfer system still favors the sole male bread-winner model and therefore causes the absolute working-time hours of economically active women to lie well below that of other Western European countries. The same pattern concerning employment rates applies to people aged 55 and older. Despite growing numbers, the actual average retirement age continues to lie well below the statutory retirement age. Since the labor supply of both groups is becoming increasingly important in determining the extent to which the working population will decrease due to the massive demographic change Germany will experience over the next 50 years, improving their employability remains one of the main challenges. Fundamentally reforming the current status quo concerning the joint taxation of married couples within a household might not be on the political agenda any time soon. Therefore, the main challenge rests upon improving the supply of childcare facilities to ensure that income support systems like PLB develop their full impact. Concerning the labor supply of older people, recent reforms of the pensions system, especially the reform in 2007 increasing the statutory retirement age to 67 from 2012 onwards, have provided the institutional framework to further increase the labor market participation of older workers. However, further potential lies within the area of lifelong learning and hence in increasing the employability of older people. Although much has been done in this area in recent years, including a number of collective agreements explicitly incorporating strategies to increase the employability of older people, training measures could still be improved to ensure that older people receive the training the really need. The ongoing technological and demographic change combined with globalization is expected to lead to a skill mismatch since low-skilled jobs in the industry will decrease and occupations requiring higher skills will increase. This will put special emphasis on the importance of educational attainment on labor market status. Especially within the area of access to tertiary education, the German government, in collaboration with the Länder has already taken up measures to meet the challenges of promoting higher skills. However, the prevalent system of early school tracking into different school types is still vulnerable to family background and increases inequality of opportunity, which led to proposals suggesting to completely withdraw from the system, or to at least postpone the decision to a later point in time.

In conclusion, the German labor market has shown remarkable resilience to the weakened economic conditions. However, meeting the challenges laid out in this paper is crucial for establishing a solid basis for continuing economic growth, in light of societal and structural changes in the country. In order to achieve this, a coordinated effort in many institutional areas, including not only income support and pensions systems, ALMPs, but also education, tax incentives and childcare, will be needed. The paper has summarized some of the current challenges and examined potential solution. 


\section{Endnotes}

${ }^{1}$ The Hartz Reforms were named after the chairman Peter Hartz, who headed the commission. The official names of the Hartz I-IV laws were Erstes, Zweites, Drittes and Viertes Gesetz für moderne Dienstleistungen am Arbeitsmarkt (Bundesministerium für Wirtschaft und Arbeit 2003).

${ }^{2}$ For an overview see, among others, Caliendo and Hujer (2006) or Imbens and Wooldridge (2009).

${ }^{3}$ The old-age dependency ratio as defined by the Federal Statistical Office is the ratio between the total number of elderly aged 65 and over and the number of those of working age (from 20 to 64).

${ }^{4}$ The Federal Statistical Office projects a total of 12 demographic scenarios up to 2060, which are based on the population level of 2008 and differ in terms of assumptions about birth rate, increase in life-expectancy, and annual net migration. The baseline scenario assumes a constant birth rate of 1.4 and an increase of the life expectancy of 7.8 (6.8) years to 85 (89.2) years for boys (girls). The annual net migration is assumed to be 100,000 individuals from 2014.

${ }^{5}$ The International Standard Classification of Education (ISCED) of the OECD divides the levels of education in six categories: Pre-primary (level 1), primary (2), lower (3) and upper (4) secondary education, tertiary (5) education, and advanced research programs (6) leading to the award of an advanced research qualification (OECD, 2011d).

${ }^{6}$ As soon as the wife starts contributing to the family income, the "splitting effect" becomes smaller. The more she contributes, the smaller is the gain from joint taxation compared to a non-married couple. The marginal tax rate on second-earners is therefore higher than for singles.

${ }^{7}$ In 1957, the German constitutional court (BVerfGE, Bundesverfassungsgericht) ruled that married couples should not be disadvantaged relative to non-married couples and that an equal share of the total household earnings belongs to each person in a marriage (BVerfGE 6, 55).

${ }^{8}$ Bundeselterngeld- und Elternzeitgesetz (BEEG).

${ }^{9}$ The monthly benefit ranges from 300 euros for low-income parents up to a maximum rate of 1,800 euros.

\section{Competing interests}

The IZA Journal of European Labor Studies is committed to the IZA Guiding Principles of Research Integrity. The authors declare that they have observed these principles.

\section{Acknowledgements}

A previous version of this paper circulated as "Income Support Systems, Labor Market Policies and Labor Supply: The German Experience". The authors thank Martin Kahanec, Alexander Kritikos, one anonymous referee, and participants at the "EU High-Level Conference on Labour Market Inclusion" in Stockholm for helpful comments.

Responsible editor: Martin Kahanec.

\section{Author details}

${ }^{1}$ University of Potsdam, IZA Bonn, DIW Berlin, IAB Nuremberg, Potsdam, Germany. ${ }^{2}$ IZA Bonn, Schaumburg-Lippe-Str. 5-9, 53113, Bonn, Germany. ${ }^{3}$ Chair of Empirical Economics, August-Bebel-Str. 89, 14482, Potsdam, Germany.

Received: 21 August 2012 Accepted: 30 August 2012

Published: 29 November 2012

References

Arnds P, Bonin H (2002) Frühverrentung in Deutschland: Ökonomische Anreize und Institutionelle Strukturen, IZA Discussion Paper 666

Arpaia A, Curci N, Meyermans E, Peschner J, Pierini F (2010) Short Time Working Arrangements as Response to Cyclical Fluctuations, European Commission 
Autorengruppe Bildungsberichterstattung (2012) Bildung in Deutschland 2012 - Ein indikatorengestützter Bericht mit einer Analyse zur kulturellen Bildung im Lebenslauf

Baumgartner H, Caliendo M (2008) Turning Unemployment into Self-Employment: Effectiveness of Two Start-Up Programmes. Oxford B Econ Stat 70(3):347-373

Berkel B, Börsch-Supan A (2003) Pension Reform in Germany: The Impact on Retirement Decisions, NBER Working Paper 9913

Bernhard S, Kruppe T (2012) Effectiveness of Further Vocational Training in Germany -Empirical Findings for Persons Receiving Means-Tested Unemployment Benefit, IAB Discussion Paper 10/2012

Bernhard S, Wolff J (2008) Contracting Out Placement Services in Germany - is Assignment to Private Providers Effective for Needy Job-Seekers? IAB Discussion Paper 05/2008

Bernhard S, Gartner H, Stephan G (2008a) Wage Subsidies for Needy Job-Seekers and Their Effect on Individual Labour Market Outcomes after the German Reforms, IZA Discussion Paper 3772

Bernhard S, Hohmeyer K, Jozwiak E, Koch S, Kruppe T, Stephan G, Wolff J (2008b) Aktive Arbeitsmarktpolitik in Deutschland und ihre Wirkungen, IAB Forschungsbericht 2/2008

Bernhard S, Brussig M, Gartner H, Stephan G (2008c) Eingliederungszuschüsse für ALG II-Empfänger: Geförderte haben die besseren Arbeitsmarktchancen, IAB Kurzbericht 12/2008

Bonin H (2009) 15 Years of Pension Reform in Germany. ZEW Discussion Paper 06-035

Börsch-Supan AH, Weiss M (2011) Productivity and Age: Evidence from Work Teams at the Assembly Line. MEA Discussion Paper Series 07148

Bundesministerium für Familie, Senioren, Frauen und Jugend (BMFSFJ) (2009) Evaluationsbericht Bundeselterngeld- und Elternzeitgesetz 2009

BMFSFJ (2010) Ausgeübte Erwerbstätigkeit von Müttern: Erwerbstätgikeit, Erwerbsumfang und Erwerbsvolumen 2010

Bundesministerium für Wirtschaft und Arbeit (2003) Moderne Dienstleistungen am Arbeitsmarkt - Bericht der Kommission zum Abbau der Arbeitslosigkeit und zur Umstrukturierung der Bundesanstalt für Arbeit

Burda MC, Hunt J (2011) What Explains the German Labor Market Miracle in the Great Recession. Brookings Pap Eco Ac 42(1):273-335

Caliendo M (2009) Start-Up Subsidies in East Germany: Finally, a Policy that Works? Int J Manpower 30(7):625-647

Caliendo M, Hujer R (2006) The Microeconometric Estimation of Treatment Effects - An Overview. Allgemeines Statistisches Archiv/Journal of the German Statistical Society 90(1):197-212

Caliendo M, Kritikos A (2009) Start-Ups by the Unemployed: Characteristics, Survival and Direct Employment Effects. Small Bus Econ 35(1):71-92

Caliendo M, Künn S (2011) Start-Up Subsidies for the Unemployed: Long-Term Evidence and Effect Heterogeneity. J Public Econ 95(3-4):311-331

Caliendo M, Steiner V (2005) Aktive Arbeitsmarktpolitik in Deutschland: Bestandsaufnahme und Bewertung der mikroökonomischen Evaluationsergebnisse. Zeitschrift für ArbeitsmarktForschung 38(2-3):396-418

Caliendo M, Hujer R, Thomsen S (2008) The Employment Effects of Job Creation Schemes in Germany - A Microeconometric Evaluation. In: Millimet DL, Smith JA, Vytlacil E (ed) Modeling and Evaluating Treatment Effects in Econometrics, Advances in Econometrics, vol 21. Elsevier, Amsterdam, pp 381-428

Caliendo M, Künn S, Schmidl R (2011) Fighting Youth Unemployment: The Effects of Active Labor Market Policies. IZA Discussion Paper 6222

Crimmann A, Wießner F (2009) Wirtschafts- und Finanzkrise - Verschnaufpause dank Kurzarbeit. IAB-Kurzbericht 14/2009

Cunha F, Heckman J (2007) The Technology of Skill Formation. Am Econ Rev 97(2):31-47

Dearing H, Hofer H, Lietz C, Winter-Ebmer R, Wrohlich K (2007) Why are Mothers Working Longer Hours in Austria than in Germany? A Comparative Microsimulation Analysis. Fiscal Studies 28(4):463-495

Deutsches Institut für Wirtschaftsforschung (2012) Elterngeld Monitor

Dietz M, Stops M, Walwei U (2011) Safeguarding Jobs in Times of Crisis - Lessons from the German Experience, International Labour Organization

Eichhorst W (2011) The Transition from Work to Retirement. IZA Discussion Paper 5490

Eichhorst W, Marx P (2009) Reforming German Labor Market Institutions: A Dual Path to Flexibility. J Eur Soc Policy 21(1):73-87

Eichhorst W, Zimmermann KF (2007) And then were four. How many (and which) measures of active labor market policy Do We still need? Appl Econ Quarterly 53(3):243-272

Esping-Andersen G (1990) The Three Worlds of Welfare Capitalism. Princeton University Press, Princeton

European Centre for the Development of Vocational Training (Cedefop) (2010) Skills Supply and Demand in Europe Medium-term Forecast up to 2020

Eurostat (2008) EU Labour Force Survey database User guide - Annex: Explanatory Notes

Eurostat (2012) Gross Profit Share of Non-Financial Corporations (Datasource: Key indicators [nasa_ki])

Fahr R, Sunde U (2009) Did the Hartz Reforms Speed-up the Matching Process? A Macro Evaluation Using Empirical Matching Functions. Ger Econ Rev 10(3):284-316

Fuchs J, Zika G (2010) Arbeitsmarktbilanz bis 2025: Demografie gibt die Richtung vor. IAB-Kurzbericht 12/2010

Fuchs J, Hummel M, Klinger S, Spitznagel E, Wanger S, Zika G (2010) Prognose 2010/2011: Der Arbeitsmarkt schließt an den vorherigen Aufschwung an. IAB Kurzbericht 18/2010

Garloff A, Pohl C, Schanne N (2012) Demografischer Wandel der letzten 20 Jahre - Alterung der Bevölkerung hat sich kaum auf die Arbeitslosigkeit ausgewirkt. IAB Kurzbericht 10/2012

Gartner H, Klinger S (2010) Verbesserte Institutionen für den Arbeitsmarkt in der Wirtschaftskrise. Wirtschaftsdienst 11:728-734

Göbel C, Zwick T (2009) Age and Productivity: Evidence from Linked Employer Employee Data. ZEW Discussion Papers 09-020

Gustafsson S (1992) Separate Taxation and Married Women's Labor Supply: A Comparison of West Germany and Sweden. J Popul Econ 5:61-85

Hanushek EA, Wössmann L (2006) Does Educational Tracking Affect Performance and Inequality? Differences- inDifferences Evidence Across Countries. Econ J 116(510):C63-C76 
Heyer G, Koch S, Stephan G, Wolff J (2011) Evaluation der aktiven Arbeitsmarktpolitik - Ein Sachstandsbericht für die Instrumentenreform 2011. IAB-Discussion Paper 17/2011

Heywood JS, Jirjahn U, Tsertsvardze G (2010) Hiring Older Workers and Employing Older Workers: German Evidence. J Popul Econ 23:595-615

Hohmeyer K (2009) Effectiveness of One-Euro-Jobs. Do Programme Characteristics Matter? AB Discussion Paper 20/2009 Hohmeyer K, Wolff J (2007) A Fistful of Euros: Does One-Euro-Job Participation Lead Means-Tested Benefit Recipients into Regular Jobs and Out of Unemployment Benefit II Receipt?. IAB Discussion Paper 32/2007

Hoßmann I, Kröhnert S, Klingholz R (2009) Kleine Erfolge. Berlin-Institut für Bevölkerung und Entwicklung

Imbens GW, Wooldridge JM (2009) Recent Developments in the Econometrics of Program Evaluation. J Econ Lit 47(1):5-86

Jacobi L, Kluve J (2007) Before and After the Hartz Reforms: The Performance of Active Labour Market Policy in Germany. Zeitschrift für ArbeitsmarktForschung 1:45-64

Kemmerling A, Bruttel O (2005) New Politics in German Labor Market Policy? WZB Discussion Paper 101

Klinger S, Rothe T (2010) The Impact of Labour Market Reforms and Economic Performance on the Matching of ShortTerm and Long-Term Unemployed. IAB-Discussion Paper 13/2010

Konle-Seidl R, Eichhorst W, Grienberger-Zingerle M (2010) Activation Policies in Germany: From Status Protection to Basic Income Support. German Policy Studies 6(1):59-100

Malmberg B, Lindh T, Halvarsson M (2008) Productivity Consequences at the Plant Level of Work-Force Ageing: Stagnation or a Horndal Effect? Popul Dev Rev 34:238-256

Manow P, Seils E (2000) Adjusting badly: the German welfare state, structural change, and the open economy. In: Scharpf FW, Schmidt VA (ed) Welfare and Work in the Open Economy, 2nd edition. pp 264-307

Möller J (2010) The German Labor Market Response in the World Recession: De-Mystifying a Miracle. Journal for Labor Market Research 42:325-336

Organisation of Economic Co-operation and Development (OECD) (2005) Ageing and Employment Policies: Germany

OECD (2010) PISA 2009 Results: Executive Summary

OECD (2011a) OECD Skills Strategy: Towards an OECD Skills Strategy

OECD (2011b) Pensions at a Glance

OECD (2011c) Doing Better for Families

OECD (2011d) Education at a Glance, OECD

OECD (2012) OECD-Wirtschaftsberichte Deutschland, OECD

Rinne U, Zimmermann KF (2011) Another Economic Miracle? The German Labor Market and the Great Recession, IZA Discussion Paper 6250

Rinne U, Schneider M, Uhlendorff A (2011) Do the Skilled and Prime-Aged Unemployed Benefit More from Training? Effect Heterogeneity of Public Training Programmes in Germany. Appl Econ 43(25):3465-3494

Sachverständigenrat zur Begutachtung der gesamtwirtschaftlichen Entwicklung (SVR) (2007) Jahresgutachten 2007/08 - Das Erreichte nicht verspielen

Schlick G (2005) Das Splitting-Verfahren bei der Einkommensteuerveranlagung von Ehegatten. Wirtschaftsdienst 2005 (5):312-319

Schneider J (2008) The Effect of Unemployment Benefit II Sanctions on Reservation Wages. IAB Discussion Paper $19 / 2008$

Schneider S, Gräf B (2010) Deutschlands Beschäftigungswunder - Kurzarbeit, flexible Tarifverträge und gesunde Unternehmen, Research Briefing. Wirtschaft und Politik, Deutsche Bank Research

Spiess CK, Wrohlich K (2008) The Parental Leave Benefit Reform in Germany: Costs and Labour Market Outcomes of Moving Towards the Nordic Model. Popul Res Policy Rev 27(5):575-591

Spitz-Oener A (2006) Technical Change, Job Tasks, and Rising Educational Demands: Looking Outside the Wage Structure. J Labor Econ 24(2):235-270

Statistik der Bundesagentur für Arbeit (2012) Kurzarbeit-Zeitreihen

Statistisches Bundesamt (2009) Bevölkerung Deutschlands bis 2060 - 12. koordinierte Bevölkerungsvorausberechnung

Steiner V, Wrohlich K (2004) Household Taxation, Income Splitting and Labor Supply Incentives: A Microsimulation Study for Germany. CESifo Economic Studies 50(3):541-568

Steinke J, Koch S, Kupka P, Osiander C, Dony E, Güttler D, Hesse C, Knapp B (2012) Neuorientierung der Arbeitsmarktpolitik Die Neuausrichtung der arbeitsmarktpolitischen Instrumente aus dem Jahr 2009 im Blickpunkt: Mehr Flexibilität und größere Handlungsspielräume für die Vermittler? IAB Forschungsbericht 2/2012

SVR (2009) Jahresgutachten 2009/10 - Die Zukunft nicht aufs Spiel setzen

SVR (2011) Herausforderungen des demografischen Wandels - Expertise im Auftrag der Bundesregierung

Tamm M (2009) The Impact of a Large Parental Leave Benefit Reform on the Timing of Birth around the Day of Implementation, Ruhr Economic Papers 98

Thyrian JR, Fendrich K, Lange A, Haas JP, Zygmunt M, Hoffmann W (2010) Changing Maternity Leave Policy: Short-Term Effects on Fertility Rates and Demographic Variables in Germany. Soc Sci Med 71:672-676

Wagner J (2011) Exports and Firm Characteristics in German Manufacturing Industries. Appl Econ Quarterly 57(2):107-143

Wanger S (2009) Altersteilzeit - beliebt aber nicht zukunftsgerecht, IAB Kurzbericht 8/2009

Wolff J, Nivorozhkin A (2008) Start me up: The Effectiveness of a Self-employment Programme for Needy Unemployed People in Germany, IAB Discussion Paper 20/2008

Wunsch C (2006) Labour Market Policy in Germany: Institutions, Instruments and Reforms since Unification. Swiss Institute for International Economics

Zwick T (2011) Why Training Older Employees is Less Effective, ZEW Discussion Paper No. 11-046

doi:10.1186/2193-9012-1-3

Cite this article as: Caliendo and Hogenacker: The German labor market after the Great Recession: successful reforms and future challenges. IZA Journal of European Labor Studies 2012 1:3. 